\title{
Helmet continuous positive airway pressure (CPAP) and arm deep vein thrombosis (DVT) in COVID-19: a double-edged sword
}

\author{
Carla Lucci ${ }^{1}$, Elena Manca Thiesi ${ }^{1}$, Federico Pappalardo ${ }^{2}$ \\ ${ }^{1}$ Ospedale Bassini, ASST Nord-Milano, Via Matteotti, Sesto SG (Milano), Italy; ${ }^{2}$ IRCCS ISMETT, UPMC Italy, Palermo, Italy \\ Correspondence to: Federico Pappalardo. Department of Anesthesia and Intensive Care, IRCCS ISMETT, UPMC Italy, Via E. Tricomi 5, 94100 \\ Palermo, Italy. Email: fedepappa.71@gmail.com.
}

Submitted May 17, 2020. Accepted for publication Feb 09, 2021.

doi: $10.21037 /$ jtd-20-1962

View this article at: http://dx.doi.org/10.21037/jtd-20-1962

Patients with COVID-19 have an increased risk for venous thromboembolism; abnormal coagulation parameters are associated with poor prognosis and existence of disseminated intravascular coagulation is common in patients dying from COVID-19 pneumonia $(1,2)$.

In COVID-19 patients, non-invasive ventilation is often delivered via helmet-continuous positive airway pressure (CPAP), assuming that it can be better tolerated for a prolonged support. The helmet might reduce environmental dispersion of virus into ambient air and therefore the risk for healthcare providers by applying a high efficiency particulate filter (HEPA) at the gas outlet. Application of helmet CPAP should focus on the fixation system as armpit straps under the axilla could provoke pain and pressure ulcers; moreover, the basilic vein diameter is increased due to blood flow drainage limitation provoked by armpit straps; counterweight strategies can mitigate the pressure exerted and increase its efficacy and tolerability (3). Yet, the collar fitting around the neck might similarly impact venous flow in the axillary vein territory. Airflow turbulence and noise can further promote hypercoagulability via activation of platelets (4).

Two male patients with COVID-19 were admitted for respiratory failure with tachycardia requiring oxygen therapy with helmet CPAP $\left(10 \mathrm{cmH}_{2} \mathrm{O}\right)$. The clinical picture was typical for SARS-COV-2 infection: activation of coagulation was shown by increased D-dimer levels (86,449 and 4,133 $\mu \mathrm{g} / \mathrm{L}$ respectively, $\mathrm{nr}$ 0-500) despite prophylactic enoxaparin (4,000 IU sc/day). Physical findings were unremarkable for patient 1 , whereas patient 2 showed unilateral arm swelling and pain.

Color Doppler vascular ultrasound examination revealed in patient 1 unilateral complete thrombosis of a collateral branch of the brachial vein draining the medial aspect of the forearm and in patient 2 omolateral massive thrombosis of the brachial, median and perforating veins of the arm. Lower limb evaluation was negative for DVT in both cases.

Anticoagulation with enoxaparin $100 \mathrm{IU} / \mathrm{kg}$ bid was started: patient 1 had complete recanalization, patient 2 reported reduction of arm swelling and partial thrombus resolution within the following 4 days. At discharge there was still thrombus at the junction between the brachial and axillary vein.

Both patients were discharged alive on full dose enoxaparin.

We recommend routine evaluation of the arms for DVT especially if helmet CPAP is applied, as it can sustain a mechanical trigger for local impairment of blood drainage. Yet, despite anticoagulation is routinely recommended in COVID-19 patients, the hypercoagulability is a major issue (5). Furthermore, we envision a rationale for preferring face mask interface for delivering CPAP in this scenario. Indeed, the deterioration of respiratory failure with high dead space requiring intubation might be sustained by episodes of asymptomatic pulmonary embolism triggered by noninvasive ventilation via helmet.

\section{Acknowledgments}

Funding: None. 


\section{Footnote}

Provenance and Peer Review: This article was a standard submission to the journal. The article was sent for external peer review.

Peer Review File: Available at http://dx.doi.org/10.21037/jtd20-1962

Conflicts of Interest: All authors have completed the ICMJE uniform disclosure form (available at http://dx.doi. org/10.21037/jtd-20-1962). Dr. FP serves as an unpaid editorial board member of Fournal of Thoracic Disease from Aug 2019 to Jul 2021. The other authors have no conflicts of interest to declare.

Ethical Statement: The authors are accountable for all aspects of the work in ensuring that questions related to the accuracy or integrity of any part of the work are appropriately investigated and resolved.

Open Access Statement: This is an Open Access article distributed in accordance with the Creative Commons Attribution-NonCommercial-NoDerivs 4.0 International License (CC BY-NC-ND 4.0), which permits the noncommercial replication and distribution of the article with the strict proviso that no changes or edits are made and the original work is properly cited (including links to both the formal publication through the relevant DOI and the license). See: https://creativecommons.org/licenses/by-nc-nd/4.0/.

\section{References}

1. Wang T, Chen R, Liu C, et al. Attention should be paid to venous thromboembolism prophylaxis in the management of COVID-19. Lancet Haematol 2020;7:e362-3.

2. Tang N, Li D, Wang X, et al. Abnormal coagulation parameters are associated with poor prognosis in patients with novel coronavirus pneumonia. J Thromb Haemost 2020;18:844-7.

3. Lucchini A, Elli S, Bambi S, et al. How different helmet fixing options could affect patients' pain experience during helmet-continuous positive airway pressure. Nurs Crit Care 2019;24:369-74.

4. Sheriff J, Tran PL, Hutchinson M, et al. The platelet hammer: In vitro platelet activation under repetitive hypershear. Annu Int Conf IEEE Eng Med Biol Soc 2015;2015:262-5.

5. Marchandot B, Trimaille A, Curtiaud A, et al. Staging Severity of COVID-19 according to Hemostatic Abnormalities (CAHA Score). Thromb Haemost 2020;120:1716-9.

Cite this article as: Lucci C, Manca Thiesi E, Pappalardo F. Helmet continuous positive airway pressure (CPAP) and arm deep vein thrombosis (DVT) in COVID-19: a double-edged sword. J Thorac Dis 2021;13(4):2563-2564. doi: 10.21037/jtd-201962 